DOI: 10.1590/0103-0582201432213113

\title{
Preterm newborns at Kangaroo Mother Care: a cohort follow-up from birth to six months
}

\author{
Recém-nascidos prematuros assistidos pelo Método Canguru: avaliação de uma coorte do nascimento \\ aos seis meses
}

Recién nacidos prematuros asistidos por el Método Canguro: evaluación de una cohorte del nacimiento a los seis meses

Maria Alexsandra da S. Menezes ${ }^{1}$, Daniela Cavalcante Garcia ${ }^{1}$, Enaldo Vieira de Melo ${ }^{1}$, Rosana Cipolotti ${ }^{1}$

\section{ABSTRACT}

Objective: To evaluate clinical outcomes, growth and exclusive breastfeeding rates in premature infants assisted by Kangaroo Mother Care at birth, at discharge and at six months of life.

Methods: Prospective study of a premature infants cohort assisted by Kangaroo Mother Care in a tertiary public maternity in Northeast Brazil with birth weight $\leq 1750 \mathrm{~g}$ and with clinical conditions for Kangaroo care.

Results: The sample was composed by 137 premature infants, being $62.8 \%$ female, with average birth weight of $1365 \pm 283 \mathrm{~g}$, average gestational age of $32 \pm 3$ weeks and $26.2 \%$ were adequate for gestational age. They have been admitted in the Kangaroo Ward with a median of 13 days of life, weighing $1430 \pm 167 \mathrm{~g}$ and, at this time, $57.7 \%$ were classified as small for corrected gestational age. They were discharged with $36.8 \pm 21.8$ days of chronological age, weighing $1780 \pm 165 \mathrm{~g}$ and $67.9 \%$ were small for corrected gestational age. At six months of life $(n=76)$, they had an average weight of $5954 \pm 971 \mathrm{~g}$, and $68.4 \%$ presented corrected weight for gestational age between percentiles 15 and 85 of the World Health Organization (WHO) weight curve. Exclusive breastfeeding rate at discharge was $56.2 \%$ and, at six months of life, $14.4 \%$.

Conclusions: In the studied sample, almost two thirds of the children assisted by Kangaroo Mother Care were, at six months of life, between percentiles 15 and 85 of the WHO

Instituição: Universidade Federal de Sergipe (UFS), São Cristóvão, SE, Brasil UUFS, SE, Brasil weight curves. The frequency of exclusive breastfeeding at six months was low.

Key-words: Kangaroo-Mother Care Method; infant, premature; growth; breast feeding.

\section{RESUMO}

Objetivo: Avaliar a evolução clínica, o crescimento e a taxa de aleitamento materno exclusivo de recém-nascidos prematuros assistidos pelo Método Canguru, ao nascimento, na alta e aos seis meses de idade.

Métodos: Estudo prospectivo de uma coorte de prematuros atendidos pelo Método Canguru, em uma maternidade pública de nível terciário do Nordeste do Brasil, com peso ao nascer $\leq 1750 \mathrm{~g}$ e em condições clínicas necessárias para se aplicar o método.

Resultados: A amostra constituiu-se de 137 recémnascidos prematuros, sendo $62,8 \%$ do sexo feminino, com peso médio ao nascer de $1365 \pm 283 \mathrm{~g}$, idade gestacional média de $32 \pm 3$ semanas e $26,2 \%$ eram adequados para a idade gestacional. Foram admitidos na Enfermaria Canguru com mediana de 13 dias de vida, pesando $1430 \pm 167 \mathrm{~g}$, sendo que, nesse momento, $57,7 \%$ foram classificados como pequeno, para a idade gestacional corrigida. Tiveram alta hospitalar com 36,8 $\pm 21,8$ dias de vida, pesando $1780 \pm 165 \mathrm{~g}$ e $67,9 \%$ eram pequenos para a idade gestacional corrigida. Aos seis meses de idade cronológica $(n=76)$, tinham peso médio de $5954 \pm 971 \mathrm{~g}$, estando $68,4 \%$ com peso corrigido

Endereço para correspondência:

Maria Alexsandra da S. Menezes

Rua Boquim, 477B - Centro

CEP 49010-280 - Aracaju/SE

E-mail: alexsandra.mar@hotmail.com

Conflito de interesse: nada a declarar

Recebido em: 15/8/2013

Aprovado em: 20/12/2013 
para a idade gestacional entre os percentis 15 e 85 da curva da Organização Mundial da Saúde (OMS). A frequência de aleitamento materno exclusivo na alta foi de $56,2 \%$ e, aos seis meses de idade cronológica, de 14,4\%.

Conclusões: $\mathrm{Na}$ amostra estudada, aproximadamente dois terços das crianças assistidas pelo Método Canguru encontravam-se, aos seis meses de idade cronológica, entre os percentis 15 e 85 da curva de peso corporal da OMS. A frequência de aleitamento exclusivo aos seis meses foi baixa.

Palavras-chave: Método Mãe-Canguru; prematuro; crescimento; aleitamento materno.

\section{RESUMEN}

Objetivo: Evaluar la evolución clínica, el crecimiento y la tasa de lactancia materna exclusiva de recién nacidos prematuros asistidos por el Método Canguro, al nacimiento, en el alta y a los seis meses de edad.

Métodos: Estudio prospectivo de una cohorte de prematuros atendidos por el Método Canguro, en una maternidad pública de nivel terciario en el Nordeste de Brasil, con peso al nacer $\leq 1750 \mathrm{~g}$ y en condiciones clínicas necesarias a la aplicación del método.

Resultados: La muestra se constituyó por 137 recién nacidos prematuros, siendo el $62,8 \%$ del sexo femenino, con peso mediano al nacer de $1365 \pm 283 \mathrm{~g}$, edad gestacional mediana de $32 \pm 3$ semanas y $26,2 \%$ eran adecuados para la edad gestacional. Se admitieron en la Enfermería Canguro con mediana de 13 días de vida, pesando $1430 \pm 167 \mathrm{~g}$ en promedio, siendo que, en ese momento, el $57,7 \%$ fueron clasificados como pequeño para la edad gestacional corregida. Tuvieron alta hospitalaria con $36,8 \pm 21,8$ días de vida, pesando $1780 \pm 165$ g y el $67,9 \%$ eran pequeños para la edad gestacional corregida. A los seis meses de edad cronológica $(n=76)$, tenían peso mediano de $5954 \pm 971 \mathrm{~g}$, estando el $68,4 \%$ con peso corregido para la edad gestacional entre los percentiles 15 y 85 de la curva de la Organización Mundial de la Salud (OMS). La frecuencia de lactancia materna exclusiva en el alta fue del 56,2\% y, a los seis meses de edad cronológica, del 14,4\%.

Conclusiones: En la muestra estudiada, aproximadamente dos tercios de los niños asistidos por el Método Canguro se encontraban, a los seis meses de edad cronológica, entre los percentiles 15 y 85 de la curva de peso corporal de OMS. La frecuencia de lactancia exclusiva a los seis meses fue baja.

Palabras clave: Método Madre-Canguro; prematuro; crecimiento; lactancia materna.

\section{Introduction}

There is an estimated annual rate of around 15 million births of preterm infants in the world, representing one in every 10 births. Many of the survivors will present learning, visual, and/or hearing problems, among others ${ }^{(1)}$.

The Kangaroo Mother Care Program or Kangaroo Method (KM), originated in Colombia in 1978, includes the skinto-skin contact between mother and newborn (NB) started as early as possible, having emerged in that country as an alternative to stimulate early hospital discharge in clinically stable low birth weight (LBW) infants ${ }^{(2)}$. In Brazil, this program's main goal is to encourage the formation of the bond between parents and babies, and it is a national health policy, launched by the Ministry of Health as Standards for Humanized Care to Low Weight Newborns - Kangaroo Method (SHCLWNB-KM), since 2000 (3).

The main benefits attributed to KM include: reduction of hypothermia, sepsis, length of hospital stay, and risk of mortality, at hospital discharge or with 40 weeks of corrected age ${ }^{(4)}$, besides positive impact on the cognitive and motor development of preterm infants ${ }^{(5)}$, maintenance of stability during transport of preterm or term infants ${ }^{(6)}$, as well as vital signs in physiological levels, even when performed in preterm infants under mechanical ventilation and hemodynamically stable $e^{(7)}$. The method avoids prolonged separation between mother and child, what could contribute for the insufficient production of milk, low affective bond, and increase of morbidities $^{(8)}$, facilitating exclusive breastfeeding for LWNB until 6 months of life ${ }^{(9)}$, besides being related to a longer period of breastfeeding and higher production of milk $^{(10)}$. In a recent systematic review published by Cochrane, the authors concluded that there is enough evidence to recommend the use of KM in stable LBW infants ${ }^{(4)}$.

However, a study assessing 176 Brazilian maternityhospitals, qualified between 2000 and 2003, shows that only $47.3 \%$ implemented the three stages of the method ${ }^{(11)}$. Véras and Traverso-Yépez ${ }^{(12)}$ state that the implementation policy of the KM does not value the social, cultural, and environmental aspects involved in motherhood. Other authors suggest that the success of the implantation of the KM depends on the training of health professionals and the facilities the hospital offers to mothers for its permanence. Furthermore, the state laws of implementation, such as those issued by the Brazilian Health Ministry, do not establish resources for the follow-up, the monitoring, and the assessment of the program. In this process, the professionals' resistance to family participation has given the KM a hospital character, 
with the extending length of rooming-in hospital stays and hospital discharge similar to conventional criteria, with inconsistencies between speech and practice ${ }^{(13)}$.

Considering these principles, the present study aimed to assess clinical progression, growth, and rate of exclusive breastfeeding of preterm infants assisted by the $\mathrm{KM}$ in a public institution of the Northeast region of Brazil in three moments: at birth, at hospital discharge, and at 6 months old.

\section{Method}

The present study used a prospective cohort, and was performed at a tertiary public maternity, in Northeastern Brazil. In this unit, there are about 4,400 deliveries per year, resulting in $31.2 \%$ LBW infants and approximately $8 \%$ very low birth weight (VLBW) newborns. The service has 36 hospital beds at the Neonatal Intensive Care Unit (NICU), 25 beds at the Intermediate Care Unit (ICU), 14 beds at the Kangaroo Ward, and 35 rooming-in beds, with mean annual occupancy rates of $121 \%$. The occupancy rate of the NICU is frequently higher than the capacity of the service, so the service recourses to improvised beds.

The study included preterm newborns (PTNB) born between July 1st, 2011 and January 31, 2012, with birth weight (BW) lower than or equal to $1,750 \mathrm{~g}$, who were in ambient air, without hydric venous support, weighing more than $1,250 \mathrm{~g}$ and whose mother had agreed to participate in the KM. Those with congenital malformations that could interfere in the evolution of the patient were excluded.

The following clinical intercurrences were researched during hospital stay: bronchopulmonary dysplasia (BPD), defined as the need for oxygen therapy for 28 days or more after birth; apnoea, defined as the interruption of air flow in the upper airways evolving to bradycardia and/or cyanosis; hypothermia, defined as axillar temperature $<36.5^{\circ} \mathrm{C}$, and need of third-line antibiotics (third generation cephalosporin or vancomycin, isolated, or in association).

Data were obtained from the analysis of the medical records; the interviews with mothers and the physical examination of the NB were always performed by the same evaluator. Some information regarding type of feeding, surgical correction of retinopathy of prematurity (ROP) after hospital discharge and need for new hospitalization were obtained also over the phone, when the consultation at 6 months old was not possible. To determine gestational age at birth, the New Ballard Score was applied ${ }^{(14)}$ and, to classify the weigh gain adequacy at birth, Alexander curves $^{(15)}$ were applied, considering adequate for gestational age (AGA) those between the $10^{\text {th }}$ and the $90^{\text {th }}$ percentiles and small for gestational age (SGA) those below the $10^{\text {th }}$ percentile. To verify the weight adequacy to corrected age, Xavier curves ${ }^{(16)}$ were applied at admission to the Kangaroo Ward and at hospital discharge; at 6 months of chronological age; the curves of the World Health Organization (WHO) were applied according to corrected age ${ }^{(17)}$.

The maternity hospital has its own protocol for the followup of preterm infants, but, for the study's data collection, an additional consultation was scheduled at 6 months of chronological age.

The evolution and assessment of weight adequacy in the PTNBs were performed in four different moments: $\mathrm{T}_{0}$, at birth; $\mathrm{T}_{1}$, at admission in the Kangaroo Ward; $\mathrm{T}_{2}$, at hospital discharge; and $\mathrm{T}_{3}$, at 6 months old.

The categorical variables were presented by means of frequency, as percentage, considering the confidence interval of $95 \%$. The mean and standard deviation were calculated for the quantitative variables. In some cases, these variables were presented as median and percentiles. For the measures of associations between qualitative variables, the Fisher exact test and the chi-square test were used. Statistical analysis was performed by the Statistical Package for the Social Sciences (SPSS) software, version 13.0 for Windows.

The project was approved by the Research Ethics Committee of Universidade Federal de Sergipe.

\section{Results}

In the studied period, 223 potentially eligible NBs were born, but 86 were excluded ( 41 due to death before admission at the Kangaroo Nursery, 41 due to non-adhesion to the method by the mother, one by maternal death, and three due to maternal refusal in participating), and the sample included 137 PTNBs.

The mean maternal age was $26 \pm 7$ years, ranging from 13 to 44 years. Mother with up to 19 years remained 24.1\% of the sample. Mothers who lived with the father of the child were $81.8 \%$; $66 \%$ declared a monthly income lower than one minimum salary and one third declared some remunerated occupation; $60.5 \%$ were from the countryside of Sergipe or from other state; $44.5 \%$ attended four or less prenatal consultations; $41.6 \%$ were primiparous. Among the mothers of the babies assessed, $44.5 \%$ had a history of pregnancy-specific hypertensive disease, $36.5 \%$ of premature rupture of membranes (PRM), and 39\% of infection of the urinary tract; $76.6 \%$ received at least one dose of antenatal corticosteroid, and $61.3 \%$ evolved to cesarean section. 
Regarding the gender, 86 NBs $(62.8 \%)$ were female. Multiple births was found in $15.3 \%$ of participants. Mean gestational age at birth was $32 \pm 3$ weeks. Data on the conditions of birth and assistance to the PTNB in the delivery room are in Table 1.

During stay at the NICU, the most common morbidities were: hypothermia (90.5\%), hypoglycemia (34.6\%), pneumonia $(14.6 \%)$, apnea $(14.6 \%)$, late sepsis $(13.9 \%)$, and bronchopulmonary dysplasia (13.1\%). In $86.1 \%$ of participants, at least one transfontanel ultrasonography was performed, with $25.5 \%$ showing some degree of hemorrhage. The screening for ROP, according to the service's

Table 1 - Conditions of birth and care of newborns in the delivery room $(n=137)$

\begin{tabular}{|c|c|c|}
\hline Variables & Mean $\pm S D$ & $\%$ \\
\hline Female & & 62.8 \\
\hline Weight (g) & $1,365 \pm 283$ & \\
\hline$\leq 1,000$ & & 13.1 \\
\hline $1,001-1,500$ & & 47.5 \\
\hline$>1,500$ & & 39.4 \\
\hline Gestational age (weeks) & $32 \pm 3$ & \\
\hline$\leq 30$ & & 8.8 \\
\hline $30-34$ & & 76.6 \\
\hline$>34$ & & 14.6 \\
\hline Adequate for gestational age & & 26.2 \\
\hline Multiple births & & 15.3 \\
\hline Apgar at $1^{\text {st }}$ minute $<7$ & & 45.4 \\
\hline Apgar at $5^{\text {th }}$ minute $<7$ & & 6.0 \\
\hline Apgar at $10^{\text {th }}$ minute $<7$ & & 2.1 \\
\hline PPV in DR & & 25.5 \\
\hline Intubation in DR & & 38 \\
\hline ECM in DR & & 1.5 \\
\hline Drugs in DR & & 0.7 \\
\hline
\end{tabular}

SD: standard deviation; PPV: positive pressure ventilation; DR: delivery room; ECM: external cardiac massage protocol, was performed at 6 weeks of life in NBs with birth weight $<1,500 \mathrm{~g}$, what corresponds to $32.8 \%$ of the studied sample. There were changes compatible with ROP in $12.4 \%$ of screened newborns. The intra-hospital surgery was performed in $2.2 \%$ of participants.

In $52.6 \%$ of cases, $\mathrm{NBs}$ needed mechanical ventilation and, in $18.2 \%$, there was need for nasal non-invasive ventilation support (CPAP). In $75 \%$ of cases, the mechanical ventilation was kept for 4 days, at most. The duration of supplementary oxygen therapy by half the sample was greater than 3 days. The surfactant was administered in $51.8 \%$ of PTNBs and, in $75 \%$, it was used in the first 20 minutes of life. A percentage of $16.8 \%$ of the sample received vasoactive drug, while $8.8 \%$ required third generation antibiotics.

At birth, the mean weight was of $1,365 \pm 283 \mathrm{~g}$ and 26.3\% were considered AGA (95\%CI 19.1-34.5). In the first 3 days of life, 109 participants $(79.5 \%)$ began the enteral diet. Maximum weight loss occurred at the $5^{\text {th }}$ day of life. Table 2 shows the weight evolution and the need for nutritional support.

Patients were admitted at the Kangaroo Nursery with median of 13 days of life (percentile $25=7$; percentile $75=28$ ), with mean weight of $1,430 \pm 167 \mathrm{~g}$. In this moment, $57.7 \%$ (95\%CI 48.9-66.1) were small for corrected age regarding the Xavier curves ${ }^{(16)}$.

The main intercurrences at the Kangaroo Ward were: anemia ( $44.5 \%)$, apnea $(7.4 \%)$, and return to the ICU or NICU due to some clinical intercurrence (6.6\%). The mean stay was $17 \pm 8$ days at the Kangaroo Nursery (interval of 3 to 48 days).

Hospital discharge occurred with $36.8 \pm 21.8$ days of life, with mean weight of $1,780 \pm 165 \mathrm{~g}$ and mean post-concepcional age of $37 \pm 5$ weeks, being $67.9 \%$ $(95 \%$ CI $59.4-75,6)$ classified as small for corrected age,

Table 2 - Weight development and need for nutritional support of newborns $(n=137)$

\begin{tabular}{|c|c|c|}
\hline Variable & Mean $\pm S D$ or Median (p25; p75) & $\%$ \\
\hline Use of parenteral nutrition & & 51.1 \\
\hline Length of parenteral nutrition* & $2(0 ; 6)$ & \\
\hline Achieved complete enteral diet* & $10 \pm 5$ & \\
\hline Weight loss at the 7 th day of life & & 8.7 \\
\hline Mean percentage of weight loss & & 10.4 \\
\hline Weight recovery at birth* & $14 \pm 7$ & \\
\hline
\end{tabular}

*In days; SD: standard deviation; p25: percentile 25; p75: percentile 75 
Table 3 - Characteristics of newborns included in the study, at hospital discharge and at 6 months old

\begin{tabular}{|c|c|c|c|}
\hline Characteristic & Mean士SD & $\%$ & $95 \% \mathrm{Cl}$ \\
\hline \multicolumn{4}{|l|}{ At discharge $(n=137)$} \\
\hline Weight $(\mathrm{g})$ & $1780 \pm 165$ & & \\
\hline Adequate weight for age & & 32.1 & $24.4-40.6$ \\
\hline Exclusive breastfeeding & & 56.2 & $48.2-64.2$ \\
\hline Mixed feeding & & 38.7 & $29.9-46$ \\
\hline Exclusive use of infant formula & & 5.1 & $2.2-8.8$ \\
\hline Hospital stay (days) & $37 \pm 22$ & & \\
\hline \multicolumn{4}{|l|}{ At 6 months $(n=76)$} \\
\hline Weight (g) & $5954 \pm 971$ & & \\
\hline Adequate weight for age & & 68.4 & $56.7-78.6$ \\
\hline Exclusive breastfeeding & & 14.4 & $8.2-21.6$ \\
\hline Mixed breastfeeding & & 26.3 & $16.5-35.1$ \\
\hline Exclusive use of infant formula & & 59.2 & $50.5-70.1$ \\
\hline
\end{tabular}

SD: standard deviation; $95 \% \mathrm{Cl}$ : confidence interval of $95 \%$

Table 4 - Evolution and weight adequacy of newborns throughout the study, according to corrected age

\begin{tabular}{lcc}
\hline & $\begin{array}{c}\text { Weight (g) } \\
\text { Mean } \pm S D\end{array}$ & $\begin{array}{c}\text { Adequacy of weight } \\
\text { for corrected age (\%) }\end{array}$ \\
\hline $\begin{array}{l}\text { At birth }(n=137) \\
\text { At admission in the EC } \\
(n=137)\end{array}$ & $1365 \pm 283$ & 26.2 \\
$\begin{array}{l}\text { Hospital discharge } \\
(n=137)\end{array}$ & $1730 \pm 167$ & 42.3 \\
At 6 months old $(n=76)$ & $5954 \pm 971$ & 32.1 \\
\hline
\end{tabular}

SD: standard deviation; KW: Kangaroo Ward

according to the Xavier curve ${ }^{(16)}$. Infants who were on breastfeeding were $94.9 \%$, with exclusive breastfeeding in $56.2 \%$ of the sample.

Information at 6 months was obtained from 99 children: 76 during follow-up visit, 21 by telephone (type of breastfeeding, readmissions in the period, and performance of corrective surgery of ROP after hospital discharge) and two through hospital records. Of the 99 infants, $16.2 \%$ were readmitted within the first 6 months of life and $3 \%$ died. Thus, 76 children ( $55.5 \%$ of the sample) were present at the return visit, in average with 186 days of chronological age and 4.5 months of corrected age. In average they weighed $5,954 \pm 971 \mathrm{~g}$, and $68.4 \%$ (95\%CI 56.7-78.6) were between the percentiles 15 and 85 , according to the WHO curves ${ }^{(17)}$. In total, $40.7 \%$ of children were breastfed, with exclusive breastfeeding in $14.4 \%$ (95\%CI 8.1-23). Table 3 shows data on the NBs at hospital discharge and at 6 months old. The progress and the weight gain adequacy in the different moments analyzed are presented in Table 4.

\section{Discussion}

Several experiences in Brazil and worldwide describe the results of the $\mathrm{KM}$ in the care of preterm newborns. Humanization in the assistance improves mother-infant bonding and is perhaps the biggest goal of this practice, seeking the earlier establishment of the relationship and decreasing the risk of abandonment and abuse ${ }^{(18)}$.

In this study, participants were young mothers, and one quarter of them, adolescents - similar to data described nationally in $2010^{(19)}$. Most were in a stable relationship, with low monthly income, did not live in the capital, and attended fewer than the 6 prenatal visits recommended by the Ministry of Health. The most prevalent maternal diseases were those that induced premature birth ${ }^{(20)}$. The mean gestational age of the sample was similar to that described by other authors ${ }^{(21)}$ in a study that assessed the results of the $\mathrm{KM}$ in Brazil, while the length of stay in the NICU was much lower in the present study, and the length of stay at the Kangaroo Ward was similar.

At birth, we classified most newborns in this study $(73.8 \%)$ as SGA, demonstrating that there was already a nutritional problem in the intrauterine period. This finding is similar to that reported in a previous study $(69 \%)^{(22)}$ and diverges from the two other studies ${ }^{(23,24)}$, in which there was a predominance of AGA infants. The characteristics of the population of pregnant women in the maternity where the study was conducted — with morbidities that characterize high risk pregnancies in almost half of them, (such as pregnancy-specific hypertensive disorder, which is a predisposing factor for the occurrence of intrauterine 
growth restriction $\left.{ }^{(25)}\right)$, besides the low income declared by almost two thirds, hampering the access to nutrients in adequate amounts $^{(22)}$ - may explain this high percentage of SGA newborns, event associated to greater neonatal mortality ${ }^{(25)}$ and greater risk of being malnourished at term $^{(23)}$. Children classified as SGA demonstrated greater growth delay in early life, but there may be late recovery ${ }^{(26)}$, justifying clinical observation during all growth period for early diagnosis and intervention.

At hospital discharge, most infants were classified as small for corrected age, similarly to what was found in the previous study, in which there was a worse weight $\mathrm{Z}$ score between birth and 40 weeks, reinforcing that the restriction of post-natal growth is a severe problem in preterm children ${ }^{(24)}$. Other authors ${ }^{(23)}$ described $63.5 \%$ of prevalence of malnutrition at term, similar value to that found in the present study.

A study comparing the evolution of newborns hospitalized in conventional intermediate care units and those admitted to Kangaroo units ${ }^{(21)}$ showed greater weight, height, and head circumference with 36 weeks of corrected age in conventional units, attributing this difference to the nutritional support at the NICU. The factors that determine the growth of preterm infants are still poorly understood, but there is data showing that it remains considerably insufficient ${ }^{(23)}$. Despite being one of the mains pillars of the KM, the frequency of exclusive breastfeeding at hospital discharge in the present study was below that found by other authors who analyzed PTNBs assisted with the $\mathrm{KM}^{(0,21,27)}$. Perhaps the low frequency of this practice has contributed to the rate of preterm infants classified as small for corrected age at hospital discharge.

The effects of postnatal growth restriction (absence or late catch up) are still unknown, including its role in the nutritional adequacy at school age, in the adolescent and the adult, and in the genesis of chronic diseases such as obesity, cardiovascular disease and diabetes, besides lack of proper cognitive development ${ }^{(28)}$.

At 6 months, there was a predominance of infants with adequate weight for corrected age, once two thirds were between the 15th and 85th percentiles of the WHO curve ${ }^{(17)}$, which is equivalent to 2 standard deviations around the mean. This recovery throughout the 1st year of life was also observed among PTNBs assisted by the KM in Colombia ${ }^{(29)}$.

The time required to reach full diet (10 5 days) was similar to that reported by other authors when analyzing 200 VLBW infants assisted by the conventional method.
In this same survey, the variable "presence of full enteral diet by the $10^{\text {th }}$ day of life" appeared as a protective factor for malnutrition at term ${ }^{(23)}$.

The results obtained in this study, evaluating hospital length of stay and need to return to the de NICU or the ICU, were similar to those obtained in previous studies $^{(21,27)}$, suggesting that the $\mathrm{KM}$ is safe, even in overcrowded units and with little human and financial resources, as in the case where the study was conducted. The frequency of apnea, higher than that of a previous study $^{(21)}$ also performed in Brazil, points to the need for more accurate monitoring and appropriate guidance to mothers at the Kangaroo Ward.

The frequency of exclusive breastfeeding in this study at the time of hospital discharge was lower than the reported by authors who analyzed $\mathrm{LW}$ infants assisted by the $\mathrm{KM}^{(9,21,27)}$. At 6 months, the frequency observed (14.4\%) was similar to that described by other authors $(22.7 \%)^{(9)}$. The low frequency of exclusive breastfeeding found may reflect regional and national characteristics. In a survey conducted in 2008 in Brazilian capitals and the Federal District, including preterm NBs with adequate weight, Aracaju had a median duration of maternal exclusive breastfeeding in younger than 6 months of 49 days, similar to that found in Recife, but lower to that described in Teresina and João Pessoa, which was of 61 days, being the national median 54 days ${ }^{(30)}$. The low rate of exclusive breastfeeding at hospital discharge and at 6 months in children assisted by the KM indicated that interventions are necessary to stimulate this practice by mothers of PTNBs, as well as to improve the understanding of the reasons why the amount of NBs in exclusive breastfeeding falls so intensely after hospital discharge.

During outpatient follow-up, in the first 6 months of life, there was a death rate of $3 \%$, similar to that obtained in a study conducted in Colombia $(6 \%)^{(25)}$. Information on the causes of the deaths could not be acquired.

A limitation of this study was the lack of a control group, which was due to the absolute majority of mothers willing to join the $\mathrm{KM}$, besides the existence of a number of beds that serves the demand of the place where the study was conducted. The combination of these two factors did not allow the formation of a comparable control group. Other limitations were time of follow-up after discharge and percentage of losses in the consultation at 6 months of life. These factors prevented the application of a multiple regression model to assess associated factors, indicating the need for further studies to complement the present findings. 
From the results obtained, it was possible to assess the growth dynamics of preterm infants assisted by the KM at a reference maternity within the Brazilian public unified health system in Northeastern Brazil. The findings show that, in the studied sample, the KM did not interfere negatively on the PTNBs' growth, increasing its potential for use in Brazilian nurseries; on the other hand, they indicate the need for new studies comparing samples of NBs treated by the two different methods, the conventional and the Kangaroo. Therefore, the results presented may be used as

\section{References}

1. March of Dimes, The Partnership for Maternal, Newborn \& Child Health, Save the Children, World Health Organtization. Born too soon: the global action report on preterm birth. Geneva: WHO; 2012.

2. Ruiz-Peláez JG, Charpak N, Cuervo LG. Kangaroo Mother Care, an example to follow from developing countries. BMJ 2004;329:1179-81.

3. Brasil - Ministério da Saúde - Secretaria de Atenção à Saúde - Departamento de Ações Programáticas Estratégicas. Atenção humanizada ao recém-nascido de baixo peso. Método Mãe Canguru. Brasília: Ministério da Saúde; 2011.

4. Conde-Agudelo A, Belizán JM, Diaz-Rossello J. Kangaroo mother care to reduce morbidity and mortality in low birthweight infants. Cochrane Database Syst Rev [serial on the Internet]. 2011;(3):CD002771 [cited 2011 Mar 16]. Available from: http://www.ncbi.nlm.nih.gov/pubmed/21412879

5. Feldman R, Eidelman Al, Sirota L, Weller A. Comparison of skin-to-skin (kangaroo) and traditional care: parenting outcomes and preterm infant development. Pediatrics 2002;110:16-26.

6. Sontheimer D, Fischer CB, Buch KE. Kangaroo transport instead of incubator transport. Pediatrics 2004;113;920-3

7. Azevedo VM, Xavier CC, Gontijo Fde O. Safety of kangaroo mother care in intubated neonates under 1500g. J Trop Pediatr 2012;58:38-42.

8. Charpak N, Ruiz JG, Zupan J, Cattaneo A, Figueroa Z, Tessier R et al. Kangaroo mother care: 25 years after. Acta Paediatr 2005;94:514-22.

9 de Almeida H, Venancio SI, Sanches MT, Onuki D. The impact of kangaroo care on exclusive breastfeeding in low birth weight newborns. J Pediatr (Rio J) $2010 ; 86: 250-3$.

10. Jefferies AL, Canadian Paediatric Society, Fetus and Newborn Committee. Kangaroo care for the preterm infant and family. Paediatr Child Health 2012;17:141-3

11. Gontijo TL, Meireles AL, Malta DC, Proietti FA, Xavier CC. Evaluation of implementation of humanized care to low weight newborns - the Kangaroo Method. J Pediatr (Rio J) 2010;86:33-9.

12. Véras RM, Traverso-Yépez M. The Kangaroo Program at a Brazilian maternity hospital: the preterm/low-weight babies' health-care under examination. Nurs Inq 2011;18:84-91.

13. Colameo AJ, Rea MF. Kangaroo Mother care in public hospitals in the State of São Paulo, Brazil: an analysis of the implementation process. Cad Saude Publica 2006;22:597-607.

14. Ballard JL, Khoury JC, Wedig K, Wang L, Eilers-Walsman BL, Lipp R. New Ballard Score, expanded to include estremely premature infants. J Pediatr 1991;119:417-23.

15. Alexander GR, Himes JH, Kaufman RB, Mor J, Kogan M. A United States national reference for fetal growth. Obstet Gynecol 1996;87:163-8. a parameter for new studies on the topic, addressing other aspects regarding the preterm's complex process of adaptation to extrauterine life.

\section{Acknowledgements}

Authors are thankful to all the staff in the Kangaroo Ward at the Nossa Senhora de Lourdes Maternity, Aracaju, state of Sergipe, especially the pediatricians Alex Santos Santana and Paulo José Melo Menezes.

16. Xavier CC, Abdallah VO, Silva BR, Mucillo G, Jorge SM, Barbieri MA. Growth of preterm newborn infants. J Pediatr (Rio J) 1995;71:22-7.

17. WHO Multicentre Growth Reference Study Group. WHO Child Growth Standards based on length/height, weight and age. Acta Paediatr 2006;450:76-85.

18. Nyqvist KH, Anderson GC, Bergman N, Cattaneo A, Charpak N, Davanzo R et al. Towards universal Kangaroo Mother Care: recommendations and report from the First European conference and Seventh International Workshop on Kangaroo Mother Care. Acta Pædiatrica 2010;99:820-6.

19. Brasil - Ministério da Saúde - DATASUS [homepage on the Internet]. Informações de Saúde - Indicadores e Dados Básicos - IDB 2011 [cited 2013 Sep 18]. Available from: http://tabnet.datasus.gov.br/cgi/tabcgi.exe?idb2011/g15.def

20. Bittar RE, Zugaib M. Risk predictors for preterm birth. Rev Bras Ginecol Obstet 2009;31:203-9.

21. Lamy Filho F, Silva AA, Lamy ZC, Gomes MA, Moreira ME; Grupo de Avaliação do Método Canguru; Rede Brasileira de Pesquisas Neonatais. Evaluation of the neonatal outcomes of the kangaroo mother method in Brazil. J Pediatr (Rio J) 2008;84:428-35.

22. Cardoso LE, Falcão MC. Growth evaluation of premature newborn infants using pre and post natal growth charts. Rev Bras Nutr Clin 2006;21:278-83.

23. Gianini NM, Vieira AA, Moreira ME. Evaluation of the nutritional status at 40 weeks corrected gestational age in a cohort of very low birth weight infant. J Pediatr (Rio J) 2005;81:34-40.

24. Rugolo LM, Bentlin MR, Rugolo Junior A, Dalben I, Trindade CE. Growth of extremely low birth weight infants during the first two years of life. Rev Paul Pediatr 2007;25:142-9.

25. Almeida MF, Mello Jorge MHP. Small for gestational age: risk factor for neonata mortality. Rev Saude Publica 1998;32:217-24.

26. Cardoso-Demartini AA, Bagatin AC, Silva RP, Boguszewski MC. Growth of preterm-born children. Arq Bras Endocrinol Metab 2011;55:534-40.

27. Penalva O, Schwartzman JS. Descriptive study of the clinical and nutritional profile and follow-up of premature babies in a Kangaroo Mother Care Program. J Pediatr (Rio J) 2006;82:33-9.

28. Casey PH. Growth of low birth weight preterm children. Semin Perinato 2008;32:20-7.

29. Charpak N, Ruiz-Pelaez JG, Figueroa de CZ, Charpak Y. A randomized, controlled trial of kangaroo mother care: results of follow-up at 1 year of corrected age. Pediatrics 2001;108:1072-9.

30. Brasil - Ministério da Saúde-Secretaria deAtenção à Saúde-Departamento deAções Programáticas Estratégicas. II Pesquisa de Prevalência de Aleitamento Materno nas Capitais Brasileiras e Distrito Federal. Brasília: Ministério da Saúde; 2009. 